\title{
Editorial: \\ Combating COVID-19: A Coordinated Efforts of Healthcare Providers and Policy Makers with Global Participation Are Needed to Achieve the Desired Goals. Mainul Haque
}

Keywords: Battling, COVID-19, Synchronized, Determinations, Healthcare Professionals, Policy Makers, Worldwide, Comprehensive, Partaking, Desirable, Accomplish, Looked-for, Objectives.

Bangladesh Journal of Medical Science, Special Issue on Covid19, 2020. Page : 01-05 DOI: https://doi.org/10.3329/bjms.v19i0.47610

The pandemic of Coronavirus disease 2019 (COVID-19) has already appeared the highest deadly human misery with death toll after the second world war ${ }^{1}$. The total global death toll till June 12, 2020, is 416,430 (Figure 1$)^{2}$. It has disrupted millions of people's lives with significant financial loss, in the meantime, the pandemic may continue for the next few years ${ }^{3-5}$. COVID-19 is a respiratory viral infectious disease with previously unknown etiology. It often causes a severe acute respiratory syndrome that first outbreak appeared in the city of Wuhan in Hubei Province, China, in December 20196, 7 Bronchoalveolar lavage fluid of COVID-19 patients, analyzed through metagenomic RNA next-generation sequencing 8 , identified a new RNA virus strain belongs to the family Coronaviridae, which is labeled as 'WH-Human 1' coronavirus9. The phylogenetic analysis assesses the sequence of a typical gene consist of the evolutionary relationship of species. The whole viral genome sequencing revealed that COVID-19 possesses 29,903 nucleotides and most closely correlated ( $89.1 \%$ nucleotide similarity) with Severe Acute Respiratory Syndrome (SARS) like coronaviruses $^{10}$.

The droplet infections remain as the primary mode of transmission for almost all respiratory infectious diseases. The droplet units with $>5-10 \mu \mathrm{m}$, and $<5 \mu \mathrm{m}$ diameter is considered as respiratory droplets and droplet nuclei, respectively ${ }^{11,12}$. Thereby, the current research shreds of evidence revealed that COVID-19 predominantly transmitted through respiratory droplets and physical contact routes ${ }^{13}{ }^{14}$. The first and foremost way of transmission COVID-19 virus primarily through respiratory salivary droplets or nasal discharge from infected individuals

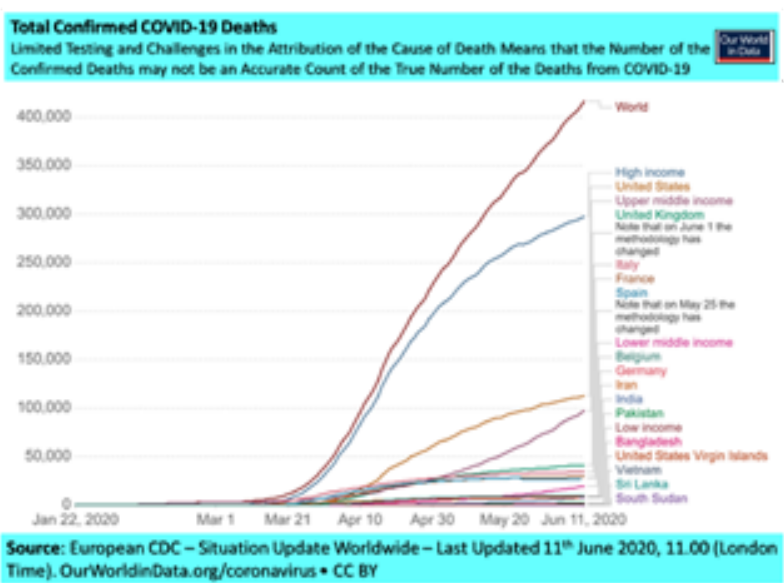

Figure 1: Illustrating the death rate around the globe with selected countries.

during coughing or sneezing ${ }^{15}$. Consequently, good respiratory etiquette practice is an essential issue for the prevention of the global pandemic of COVID-19 ${ }^{16,17}$. Subsequently, the World Health Organization (WHO) promotes social distancing, frequent hand-wash, regular use of face mask for the prevention of the global pandemic ${ }^{18-20}$. To date, no specific vaccines or pharmacological interventions for COVID-19 are available ${ }^{21}$, and "the COVID-19 pandemic represents the greatest global public health crisis of this generation and, potentially, since the pandemic influenza outbreak of $1918{ }^{21}$.

Several studies have reported that the incubation time of COVID-19 from infection to appearance of symptoms and signs takes five to six days [5.2 days ( $95 \%$ confidence interval [CI], 4.1 to 7.0$)]^{22}$, and the average range of one-two weeks ${ }^{22-25}$. The number of days from the earliest symptom to passing away was 14.0 (range 6-41) days, and it leans towards to be

Correspondence to: Mainul Haque, Professor of the Unit of Pharmacology, Faculty of Medicine and Defence Health, Universiti Pertahanan Nasional Malaysia (National Defence University of Malaysia), Kem Sungai Besi, 57000 Kuala Lumpur, Malaysia.

Email: runurono@gmail.com Orcid ID : http://orcid.org/0000-0002-6124-7993 
petite amid COVID-19 patients' 70 years and above [11.5 (range 6-19) days] than those were below 70 years [20 (range 10-41) days; $P=0.033$ ]. ${ }^{26}$ The most typical symptoms of COVID-19 include fever $(98 \%)$, cough $(76 \%)$, myalgia, or fatigue $(44 \%)$, followed by sputum production (28\%), headache $(8 \%)$, hemoptysis $(5 \%)$, and diarrhea $(3 \%)$. Around $55 \%$ of patients develop dyspnea 8.0 days [IQR $5 \cdot 0-13 \cdot 0]$ ), and $63 \%$ had lymphopenia ${ }^{27}$. Another study revealed that $58 \%$ and $39.9 \%$ of patients develop prolonged prothrombin time [13.0 seconds (Interquartile Range (IQR), 12.3-13.70)], and elevated lactate dehydrogenase [261 U/L (IQR, 182403)], respectively ${ }^{28}$. Chest computed tomographic (CT) scans revealed abnormal features such as serum SARS-CoV-2 nucleic acid (RNAemia), acute respiratory distress syndrome, severe cardiac damage, and two-sided patchy shadows or ground-glass opacities in the lungs that led to death ${ }^{28,29}$. Noticeable RNAemia in COVID-19 patients were correlated with high-level Interleukin 6 (IL-6) and poor clinical outcomes. As high-level IL-6 often involved in a more massive cytokine storm that could deteriorate clinical outcomes. Thereby, IL-6 denotes excessive inflammatory responses, and therapeutic intervention to address this area may possess potential benefits among COVID-19 patients p $^{30-32}$.

The WHO demarcated primary health care (PHC) "is a whole-of-society approach to health and wellbeing centered on the needs and preferences of individuals, families, and communities. It addresses the broader determinants of health and focuses on the comprehensive and interrelated aspects of physical, mental, and social health and wellbeing" ${ }^{33}$. Additionally, PHC delivers wholeperson health care needs during the lifespan, not to treat some particular diseases. PHC makes certain people obtain comprehensive healthcare - extending from promotion and prevention to treatment, rehabilitation, and palliative care - as close as practicable to the ordinary public's run-of-the-mill environment ${ }^{33},{ }^{34}$. Covid-19 - the global pandemic has toppled the current social order and intensely transformed everyday lifestyle around the globe. PHC Performance Initiative think-tank believes "strong PHC delivers a critical first line of defense and response to keep people safe and healthy. PHC systems can help diagnose, track, and stop the spread of local outbreaks while providing essential health services to communities" ${ }^{35}$. The PHC can serve and provide over $80 \%$ of people's health needs of any age and stage of life. Consequently, those countries heavily invested in PHC are much better equipped to handle the current global pandemic. It is for instance, Taiwan, after the 2003 SARS outbreak, heavily devoted and financed in its PHC and for development of PHC health professionals, which have faith in community care systems as first-line combatants to fight against unexpected healthcare disasters $^{35,36}$. After that, multiple research studies again emphasized on strengthening the PHC program all over the globe, as an urgent issue to deal with such pandemic as COVID-1937-39. Earlier studies from the USA reported that around 14.2-24.7 million the Americans developed influenza during 2001-2003. Thereby, there were nearly 31.4 million patients taken to outpatient hospital service for influenza-related complications, and 334,185 needed hospitalization and 41,008 patients passed away ${ }^{40-43}$. Two British studies have reported that there had been more than 1500 extra patients with outpatient visits to primary care services per 100,000 Britishers in the course of the peak week of the influenza-pandemic ${ }^{44,45}$. PHC system extend the healthcare service irrespective of race, ethnicity, major or minority community, financial status, living in an urban or rural area, uninsured, and underprivileged equally, and promote equity ${ }^{46-49}$.

The current global pandemic COVID-19 is exposing the limitation of the existing healthcare system around the planet, despite enormous scientific progress in medical science in the last 100 years $^{50}$. Covid-19 goes beyond routine medical care and needs the participation of all the stakeholders of the healthcare system further than medical care professionals of clinical importance ${ }^{51-52}$. A befitting need-based health policy planning according to the context of a country, and consequently, implementation of such strategies remain as an essential step to follow ${ }^{50}$. PHC is a comprehensive program that involves all the stakeholders, along with community participation ${ }^{34}$, 53-55. At this point development of healthcare policy planning should be based on PHC probably the best available approach for combatting against the current pandemic and to face any future health disaster. 


\section{References:}

1. O’Grady S, Noack R, Mettler K, Knowles H, Armus T, Wagner J, Shammas B, Berger M. U.S. records more than 2,000 coronavirus deaths in one day, global death toll reaches 100,000. 2020. The Washing Post. Available at https://www.washingtonpost.com/world/2020/04/09/ coronavirus-latest-news/ [Accessed June 12, 2020]

2. Roser M, Ritchie H, Ortiz-Ospina E, Hasell J. Statistics, and Research. Coronavirus (COVID-19) Deaths. 2020. Available at https://ourworldindata.org/coviddeaths\#what-is-the-total-number-of-confirmed-deaths [Accessed June 12, 2020]

3. Scott J. The economic, geopolitical, and health consequences of COVID-19. World Economic Forum. World Economic Forum. 2020. Available at https:// www.weforum.org/agenda/2020/03/the-economicgeopolitical-and-health-consequences-of-covid-19/ [Accessed June 12, 2020]

4. Timsit A. Irreplaceable. Coronavirus is causing people to miss once-in-a-lifetime moments. 2020. Médecins Sans Frontièr (Doctors Without Borders) Available at https:// qz.com/1817359/covid-19-is-making-people-canceltheir-most-important-life-events/ [Accessed June 12, 2020]

5. International Monetary Fund. Policy Responses to COVID-19, 2020. Available at https://www.imf.org/ en/Topics/imf-and-covid19/Policy-Responses-toCOVID-19 [Accessed June 12, 2020]

6. Khadka S, Hashmi FK, Usman M. Preventing COVID-19 in low- and middle-income countries. Drugs Ther Perspect. 2020;1-3. doi:10.1007/s40267-020-00728-8

7. Mackenzie JS, Smith DW. COVID-19: a novel zoonotic disease caused by a coronavirus from China: what we know and what we don't. Microbiol Aust. 2020; MA20013. doi:10.1071/MA20013

8. Shi M, Lin XD, Tian JH, et al. Redefining the invertebrate RNA virosphere. Nature. 2016;540(7634):539-543. doi:10.1038/nature20167

9. Wu F, Zhao S, Yu B, et al. A new coronavirus associated with human respiratory disease in China. Nature. 2020;579(7798):265-269. doi:10.1038/s41586-0202008-3

10. $\mathrm{Hu} \mathrm{D}, \mathrm{Zhu} \mathrm{C}, \mathrm{Ai} \mathrm{L}$, et al. Genomic characterization and infectivity of a novel SARS-like coronavirus in Chinese bats. Emerg Microbes Infect. 2018;7(1):154. doi:10.1038/s41426-018-0155-5

11. World Health Organization. Infection prevention and control of epidemic- and pandemic-prone acute respiratory infections in health care. Geneva: World Health Organization; 2014 Available at https://apps.who.int/iris/ bitstream/handle/10665/112656/9789241507134_eng. pdf? sequence $=1$ [Accessed June 12, 2020]

12. Atkinson J, Chartier Y, Pessoa-Silva CL, et al., editors. Natural Ventilation for Infection Control in Health-Care Settings. Geneva: World Health Organization; 2009.
Annex C, Respiratory droplets. Available at https:// www.ncbi.nlm.nih.gov/books/NBK143281/ [Accessed June 12, 2020]

13. Guo YR, Cao QD, Hong ZS, et al. The origin, transmission, and clinical therapies on coronavirus disease 2019 (COVID-19) outbreak - an update on the status. Mil Med Res. 2020;7(1):11. doi:10.1186/s40779020-00240-0

14. American Society of Microbiology. COVID-19 Transmission Dynamics. 2020. Available at https://www. asm.org/Articles/2020/April/COVID-19-TransmissionDynamics [Accessed June 12, 2020]

15. Hsiao TC, Chuang HC, Griffith SM, Chen SJ, Young LH. COVID-19: An Aerosol's Point of View from Expiration to Transmission to Viral-mechanism. Aerosol and Air Quality Research, 20: 905-910, 2020. doi: 10.4209/ aaqr.2020.04.0154

16. Qian X, Ren R, Wang Y, et al. Fighting against the common enemy of COVID-19: a practice of building a community with a shared future for mankind. Infect Dis Poverty. 2020;9(1):34. doi:10.1186/s40249-020-006501

17. Viner RM, Russell SJ, Croker H, et al. School closure and management practices during coronavirus outbreaks including COVID-19: a rapid systematic review. Lancet Child Adolesc Health. 2020;4(5):397-404. doi:10.1016/ S2352-4642(20)30095-X

18. World Health Organization. Advice on the use of masks in the context of COVID-19. 2020. Interim guidance. WHO reference number: WHO/2019-nCov/ IPC_Masks/2020.4. Available at https://apps.who.int/ iris/rest/bitstreams/1279750/retrieve https://www.asm. org/Articles/2020/April/COVID-19-TransmissionDynamics [Accessed June 12, 2020]

19. World Health Organization. Non-pharmaceutical public health measures for mitigating the risk and impact of epidemic and pandemic influenza. Annex: Report of systematic literature reviews. Global Influenza Program. 2019. Licence: CCBY-NC-SA3.0IGO. Available at https://apps.who.int/iris/rest/bitstreams/1279750/ retrieve https://www.asm.org/Articles/2020/April/ COVID-19-Transmission-Dynamics [Accessed June 12, 2020]

20. Nicola M, O’Neill N, Sohrabi C, Khan M, Agha M, Agha R. Evidence-based management guideline for the COVID-19 pandemic - Review article. Int J Surg. 2020; 77:206-216. doi: 10.1016/j.ijsu.2020.04.001

21. Sanders JM, Monogue ML, Jodlowski TZ, Cutrell JB. Pharmacologic Treatments for Coronavirus Disease 2019 (COVID-19): A Review. JAMA. 2020;10.1001/ jama.2020.6019. doi:10.1001/jama.2020.6019

22. Li Q, Guan X, Wu P, et al. Early Transmission Dynamics in Wuhan, China, of Novel Coronavirus-Infected Pneumonia. N Engl J Med. 2020;382(13):1199-1207. doi:10.1056/NEJMoa2001316

23. Zhai P, Ding Y, Wu X, Long J, Zhong Y, Li Y. The 
epidemiology, diagnosis, and treatment of COVID-19. Int $J$ Antimicrob Agents. 2020;55(5):105955. doi: 10.1016/j.ijantimicag.2020.105955

24. Cennimo DJ. What is the incubation period for coronavirus disease 2019 (COVID-19)? 2020. Available at https:// www.medscape.com/answers/2500114-197431/whatis-the-incubation-period-for-coronavirus-disease-2019covid-19 [Accessed June 12, 2020]

25. He X, Lau EHY, Wu P, et al. Temporal dynamics in viral shedding and transmissibility of COVID-19. Nat Med. 2020; 26, 672-675. doi: 10.1038/s41591-020-0869-5

26. Wang W, Tang J, Wei F. Updated understanding of the outbreak of 2019 novel coronavirus (2019-nCoV) in Wuhan, China. J Med Virol. 2020;92(4):441-447. doi:10.1002/jmv.25689

27. Huang C, Wang Y, Li X, et al. Clinical features of patients infected with 2019 novel coronavirus in Wuhan, China. Lancet. 2020;395(10223):497-506. doi:10.1016/ S0140-6736(20)30183-5

28. Wang $\mathrm{D}, \mathrm{Hu} \mathrm{B}, \mathrm{Hu} \mathrm{C}$, et al. Clinical Characteristics of 138 Hospitalized Patients with 2019 Novel CoronavirusInfected Pneumonia in Wuhan, China. JAMA. 2020;323(11):1061-1069. doi:10.1001/jama.2020.1585

29. Rothan HA, Byrareddy SN. The epidemiology and pathogenesis of coronavirus disease (COVID-19) outbreak. J Autoimmun. 2020; 109:102433. doi: 10.1016/j.jaut.2020.102433

30. Chen X, Zhao B, Qu Y, et al. Detectable serum SARSCoV-2 viral load (RNAemia) is closely correlated with drastically elevated interleukin 6 (IL-6) level in critically ill COVID-19 patients. Clin Infect Dis. 2020; ciaa449. doi:10.1093/cid/ciaa449

31. Zhang C, Wu Z, Li JW, Zhao H, Wang GQ. Cytokine release syndrome in severe COVID-19: interleukin-6 receptor antagonist tocilizumab may be the key to reduce mortality. Int J Antimicrob Agents. 2020;55(5):105954. doi: 10.1016/j.ijantimicag.2020.105954

32. Liu B, Li M, Zhou Z, Guan X, Xiang Y. Can we use interleukin-6 (IL-6) blockade for coronavirus disease 2019 (COVID-19)-induced cytokine release syndrome (CRS)? J Autoimmun. 2020; 111:102452. doi: 10.1016/j. jaut.2020.102452

33. World Health Organization. Primary health care. Key facts. 2019. Available at https://www.who.int/newsroom/fact-sheets/detail/primary-health-care [Accessed June 13-2020]

34. Haque M, Islam T, Rahman NAA, McKimm J, Abdullah A, Dhingra S. Strengthening Primary Health-Care Services to Help Prevent and Control Long-Term (Chronic) Non-Communicable Diseases in Low- and Middle-Income Countries. Risk Manag Healthc Policy. 2020; 13: 409-426. doi: 10.2147/RMHP.S239074

35. Primary Health Care Performance Initiative. Key Messages: COVID-19 and Primary Health Care. 2020. Available at https://improvingphc.org/sites/default/
files/FINAL COVID-19\%20and $\% 20$ Primary $\% 20$ Health\%20Care.pdf [Accessed June 13-2020]

36. World Health Organization. WHO and European Investment Bank strengthen efforts to combat COVID-19 and build resilient health systems to face future pandemics. 2020. Available at https://www.who. int/news-room/detail/01-05-2020-who-and-europeaninvestment-bank-strengthen-efforts-to-combat-covid19-and-build-resilient-health-systems-to-face-futurepandemics [Accessed June 13-2020]

37. Lim WH, Wong WM. COVID-19: Notes from the Front Line, Singapore's Primary Health Care Perspective. Ann Fam Med. 2020;18(3):259-261. doi:10.1370/afm.2539

38. Souza CDF, Gois-Santos VT, Correia DS, Martins-Filho PR, Santos VS. The need to strengthen Primary Health Care in Brazil in the context of the COVID-19 pandemic. Braz Oral Res. 2020;34: e047. doi:10.1590/18073107bor-2020.vol34.0047

39. Sarti TD, Lazarini WS, Fontenelle LF, Almeida APSC. What is the role of Primary Health Care in the COVID-19 pandemic? Epidemiol Serv Saude. 2020;29(2): e2020166. doi:10.5123/s1679-49742020000200024

40. Clayville LR. Influenza update: a review of currently available vaccines. P T. 2011;36(10):659-684.

41. Rust G, Melbourne M, Truman BI, Daniels E, FryJohnson Y, Curtin T. Role of the primary care safety net in pandemic influenza. Am J Public Health. 2009;99(Suppl 2): S316-S323. doi:10.2105/AJPH.2009.161125

42. Soni A, Hill SC. Average Annual Health Care Use and Expenses for Influenza, 2001-2003. Rockville, MD: Agency for Healthcare Research and Quality; March 2006. Statistical Brief 116. Available at http://meps.ahrq. gov/mepsweb/data files/publications/st116/stat116.pdf [Accessed June 14, 2020]

43. Molinari NA, Ortega-Sanchez IR, Messonnier $\mathrm{ML}$, et al. The annual impact of seasonal influenza in the US: measuring disease burden and costs. Vaccine. 2007;25(27):5086-5096. doi: 10.1016/j. vaccine. 2007.03 .046

44. The Central Office of Information, for the Department of Health and the Cabinet Office, UK. Pandemic Flu. A national framework for responding to an influenza pandemic. 2007. Available at http://antibiotic-action. com/wp-content/uploads/2011/07/DH-Pandemicinfluenza-a-national-framework-v2007.pdf [Accessed June 14, 2020]

45. The Pandemic Influenza Preparedness Team. Pandemic influenza Surge capacity and prioritization in health services. The Central Office of Information, for the Department of Health and the Cabinet Office, UK. Department of Health, 452C Skipton House, 80 London Road, London SE1 6LH. 2008. Available at https:// cdn.ps.emap.com/wp-content/uploads/sites/3/2009/05/ surgeguidance.pdf [Accessed June 14, 2020]

46. Wong ST, Browne AJ, Varcoe C, et al. Development of health equity indicators in primary health care 
organizations using a modified Delphi. PLoS One. 2014;9(12): e114563. doi: 10.1371/journal. pone. 0114563

47. Barrett R, Brown PJ. Stigma in the time of influenza: social and institutional responses to pandemic emergencies. J Infect Dis. 2008;197 Suppl 1: S34-S37. doi:10.1086/524986

48. Browne AJ, Varcoe C, Lavoie J, et al. Enhancing health care equity with Indigenous populations: evidence-based strategies from an ethnographic study. BMC Health Serv Res. 2016;16(1):544. doi:10.1186/s12913-016-1707-9

49. Browne AJ, Varcoe C, Ford-Gilboe M, et al. Disruption as opportunity: Impacts of an organizational health equity intervention in primary care clinics. Int $J$ Equity Health. 2018;17(1):154. doi:10.1186/s12939-018-0820-2

50. Raoofi A, Takian A, Akbari Sari A, Olyaeemanesh A, Haghighi H, Aarabi M. COVID-19 Pandemic and Comparative Health Policy Learning in Iran. Arch Iran Med. 2020;23(4):220-234. doi:10.34172/aim.2020.02

51. Tay K, Kamarul T, Lok WY, et al. COVID-19 in Singapore and Malaysia: Rising to the Challenges of
Orthopaedic Practice in an Evolving Pandemic. Malays Orthop J. 2020;14(2):10.5704/MOJ.2007.001.

52. Fontanarosa PB, Bauchner H. COVID-19-Looking Beyond Tomorrow for Health Care and Society. JAMA. 2020;10.1001/jama.2020.6582 . doi:10.1001/ jama.2020.6582

53. World Health Organization and the United Nations Children's Fund (UNICEF) A Vision for Primary Health Care in the 21st Century. Technical Series on Primary Health Care. (WHO/HIS/SDS/2018.X). License: CC BY-NC-SA 3.0, 2018 Available at https://www.who. int/docs/default-source/primary-health/vision.pdf [Accessed June 14, 2020]

54. White F. Primary health care and public health: foundations of universal health systems. Med Princ Pract. 2015;24(2):103-116. doi:10.1159/000370197

55. Bath J, Wakerman J. Impact of community participation in primary health care: what is the evidence? Aust J Prim Health. 2015;21(1):2-8. doi:10.1071/PY12164 